\title{
Discursive Heterogeneity in The Autobiography of Miss Jane Pittman by Ernest J. Gaines
}

\author{
Daniel Tia (Corresponding author) \\ Department of English, American Studies, University of Félix Houphouët-Boigny \\ Abidjan-Cocody, Côte d'Ivoire \\ Assistant Professor \\ E-mail: yawejanet@yahoo.com
}

Received: March 20, 2021 Accepted: April 22, $2021 \quad$ Published: April 22, 2021

doi:10.5296/ijch.v8i1.18555 URL: https://doi.org/10.5296/ijch.v8i1.18555

\begin{abstract}
Various critics are interested in the aesthetic scope of literary discourse; those who are truly inscribed in that perspective, adopt varied approaches. Accordingly, countless meanings are given to the same literary texts. What is termed "discursive heterogeneity" in the current study is purely ideological and is about the implicit views entertained by colonists during and after colonial period, which are symbolically romanticized by African American writers as illustrated by Ernest J. Gaines in The Autobiography of Miss Jane Pittman (Note 1). That novel is a symbolic instance in which a double period, marked by distinctive ideological discourses, intertwine in a unified and dynamic way, thus creating a narrative harmony. The former differs from the latter by its unilateral characteristics, which imposes an exclusive submission upon Blacks and the latter is opposed to the former by its controversial ambivalence, granting restricted liberties to Blacks. Practically, Blacks are free without actually being free. A close glance at the type of communication prevailing between white colonists and black folks before the Proclamation of Freedom helps to discover its unilateralism (downward communication) and the post-Proclamation one is bi-dimensional (downward and upward communication). But between both preceding periods, there is the Proclamation of Freedom, whose message is more constraining and transcendental in the narrative universe. So, to learn more about that "discursive heterogeneity" and bring out its related meanings, this study leans on narrative semiotics. That methodological tool examines the discursive clues; particular attention is paid to Blacks' evolution from the period before the Proclamation of Freedom up to the prevailing era after the Emancipation.
\end{abstract}


Keywords: literary discourse, colonial ideology, conversational maxims, downward and upward communication, Proclamation of Freedom, conversational implicature

\section{Introduction}

A critical study upon "discursive heterogeneity" in The Autobiography is of interest, for it contributes to interrogate the dialogical acts recurrent in the narrative space. Obviously, those interactions generate a relevant semantic network for the understanding of Gaines's fiction. "But before scrutinizing the features of "discursive heterogeneity" and its implied significance, it is paramount to consider some of the critical studies already carried out upon Gaines's novel. Among others, there are Laurence Cossu-Beaumont's « La Réception de The Autobiography of Miss Jane Pittman : Du consensus à la polémique, du best-seller au « classique » (2005), Ada Savin's “The Autobiography of Miss Jane Pittman: Some Generic Distinctions" (2005), Christopher Mulvey's “The History of Miss Jane Pittman: Ernest J. Gaines and the Slave Narrative" (2006), Adeboye A., Johnson's "The Shifting Features of Leadership in Ernest Gaines's The Autobiography of Miss Pittman" (2008), B. Evayoulou, "The Autobiography of Miss Jane Pittman and the Tradition of the African American Historical Novel" (2011), Daniel Thomières's “Man's Way and Woman's Way in The Autobiography of Miss Jane Pittman" (2011), Yapo Ettien's "Ernest J. Gaines's Miss Jane Pittman: A Symbol of The Black Female Abolitionist Struggle" (2014), Ferdinand Kpohoue, Sènakpon A. Fortuné Azon, and Armand Kougnanvo's “African Americans' Empowerment through Individual Endeavor and Local Leadership in The Autobiography of Miss Jane Pittman by Ernest Gaines (2017). Each of those critical works explains a specific aspect of the author's text; some examine its historical background, others question its political and feminist aspects. Together, they are constructive and contributive. But, as we can notice, none of them shows how colonial, emancipatory, and post-emancipatory ideologies participate in the poetics of heterogeneity in this novel. The three ideologies belong to different periods whose impacts upon Whites and Blacks' relationship have particular characteristics, which need to be deciphered. The verbal exchanges between the characters (white \& black) acting in the narrative universe are sometimes wrecked, sometimes established. Apparently, this novel features two social categories of characters, which can be symbolized as followed: $B \& N$. One is White, rich, intellectual, and independent enough; the other one is Black, poor, uneducated, subordinate, deported, and dependent on $B$.

$B$ expresses itself in a formal language and $N$ in an informal one. Those differences give rise to a hateful view and a relationship of selfishness marked by tears. Accordingly, $B$ denigrates $N$ considering it as an enemy; its members adopt a brutal and ignoble attitude toward those of $N$ and reduce them to sub-humans, objects, cattle to be owned or traded. In this conflicting context, $B$ maintains an ideological discourse full of prejudice, arbitrariness and domination, which associates verbal and physical violence leaving no possibility of self-emergence or self-achievement to $N$. Being entirely dumbed down, members of $N$ are unable to challenge or contradict the words of those of $B$. Ignorant of the sense of individual and collective liberties, never having experienced them, because zoologized by $B$, members of $N$ are blindly submissive to the orders of those of $B$. 
But, the "social facts" being dynamic, the advent of the Proclamation of Freedom or "Proclamation Emancipation" brings a new era, deal, behavior, and consideration. Subsequently, this inaugurates an original order called by Nicole Everaert Desmedt (1989) "Transformation". To her, that can be "abrupt", "progressive," and "unexpected". The ideology of the Proclamation of Freedom imposes peace and human dignity, establishes a new vision in the colonists' habits and language. As to the post-Proclamation ideology, which is symbolically named "post-colonial era," it covers an ambivalent, imprecise or contradictory scope. Members of $N$ are bestowed conditioned and non-defined freedom. They are free and have the possibility to construct their own lives, to move around, but they are held back in their momentum, thus making the ideals of that emancipation more problematic and even uncertain.

A close glance at the trajectory of members of $B$ and $N$, helps to set them on a semantic axis, which represents the "narrative structure" of the novel under study. With reference to the narrative semiotics advocated by Desmedt, "the semantic axis is inscribed in a temporal succession" (Translation mine) (Desmedt, 1989) that is illustrated by the following set: $\left\{\mathrm{S}_{(\mathrm{E})}\right.$; $\mathrm{T}_{(\mathrm{RA} / \mathrm{C} / \mathrm{FA})} ; \mathrm{S}_{(\mathrm{E})\}}$ (Note 2). Those three items respectively designate Initial situation (exposition), Transformation (raising action, climax, falling action), and Final situation (resolution or denouement). To comprehend the meanings generated by that "discursive heterogeneity," particular attention will be paid to the study of each of the three items, namely the colonial, emancipatory, and post-emancipatory ideologies.

\section{The Discursive Colonial Matrix}

This step aims to question the "systems of values" related to colonial ideology. So, to be logical and avoid confusion, it is relevant to focus on some particular utterances taken The Autobiography. Those utterances are chosen on the basis of the implicit and substantial values they embody. Indeed, to Yves Reuter, "[a] novel is a multifarious genre, which can take on various aspects" (Translation mine) (Reuter, 2011). Analyzing how systems of values are formed in literary texts, Jacques Fontanille notes: "To perceive something, even before recognizing it as a figure belonging to one of the two macro-semiotics, is to perceive a presence more or less intensely. Indeed, before identifying a figure in the natural world, or even a notion or a feeling, we perceive (or "sense") its presence, that is to say, something that, on the one hand, occupies a certain position, relative to our own position, and a certain extent, and that, on the other hand, affects us with a certain intensity; something, in short, that orients our attention, that resists it or that offers itself to it" (Translation mine) (Fontanille, 1999).

In point of fact, Gaines's novel incorporates various dominant values, which are linked to colonial ideology whose proponents' single objective is to conquer other cultures and deliberately impose their civilization on them. Achille Mbembe openly reveals that unstated objective in his Critique de la Raison Nègre (2013): "From the colonial relentlessness to divide, classify, hierarchize, and differentiate, something has remained, nicks, even lesions" (Translation mine) (Mbembe, 2013). That disagreeableness is obvious in the Gaines's text. So, to question them, let us consider the following utterances: " $a$ - My Mistress told me stop standing there gaping, go out there in the road and give the Troops some water./b- Go fill that 
barrel./c- Take her to the swamps and kill her, my Mistress said" (Gaines, 1971).

The utterances $a, b$ and $c$ are reported by a young slave called Ticey; she reports her white Mistress's words. The utterances $a, b$, and $c$ describe a very particular dialogue. The Mistress speaks to Ticey, a young black slave who works for her family. Here, the enunciative context depicts two interlocutors (Mistress and Ticey) (Note 3), but only the Mistress has the right to speak. Her co-speaker's exclusive duty is to execute the orders, for the slavery code requires her to be submissive (execution without opposition/submission without disobedience). In her utterances, the Mistress uses distinct action verbs, inter alia told, stop, and go out, give, go fill, take, and kill. Those italicized verbs share a same denominator (value) -they have a pragmatic scope and imply specific actions, which when fully assumed, accomplish and satisfy the speaker's will. At this level, the speaker $M$ does not show any act of politeness toward the co-speaker $T$, but rather an act of compulsion. To Buyssens, "every sentence has one of four functions: to inform the listener, to question the listener, to give the listener an order, to take the listener to witness a vow. There is no other possibility" (Translation mine) (Buyssens quoted by Catherine Kerbrat-Orecchioni, 1986).

With reference to Buyssens's view, the verbs enumerated above have a performative value (scope). They establish an unequal relationship between Whites and Blacks - the latter work for the former and evolve under their authority. The utterances $a, b$ and $c$ are full of threat. That is, when the actions intended by the speaker $M$ are not assumed or carried out, the co-speaker $T$ is severely sanctioned. For example, the following utterances reveal the constraining scope of the three previous ones: " $d$ - I better do it, Master, I said./e- They whip me if I don't do my job" (Gaines, 1971). The utterances $d$ and $e$ predict the eventual sanction, which may be inflicted upon Ticey if she does not provide the soldiers of both of the belligerent Armies (Secesh and Yankees) with water. Those utterances show that Ticey is alienated; she is compelled to execute her Mistress' orders to avoid being whipped. Ticey's unique role is to carry out the orders given by her Mistress.

Any acts of disobedience are representative of insubordination or rebellion and thus are punished. To Jalal Mostafaee, "the colonizer violently imposes his superiority to the colonized, but is always anxiously pondering his identity" (Mostafaee, 2016). Explicitly, the interaction between the white Mistress $M$ and her black slave $T$ is inherently downward; only the Mistress speaks and the co-speaker $T$ executes the orders. So, it can be inferred that the colonial discourse resorts to brute force and acts of intimidation to achieve its objectives. Those characteristics keep slaves under pressure and worsen their social conditions and psychological state; they are haunted by fear. To Gilles Siouffi and Dan Van Raemdonck, "performative enunciation is the one which amounts to doing something by the mere fact of stating it" (Translation mine) (Siouffi \& Raemdonck, 1999).

Importantly, the utterances $a, b$ and $c$ are not merely acts of communication. They epitomize colonial ideology, which is internalized by the white speaker $M$ and externalized when speaking to her slave (Ticey). Mbembe's viewpoint contains some of the essential features of colonial ideology, which are illustrated in Gaines's text. Better still, colonial ideology has a double scope: it informs the co-speaker; but beyond that informative aspect, it has a 
pragmatic scope. In other words, colonial ideology compels the co-speaker to react; its scope is extratextual and endowed with a certain authority. To Oswald Ducrot, "an order or request statement says that its enunciation compels (with modalities according to the two cases) the person to whom the acts are addressed to adopt a certain behavior" (Translation mine) (Ducrot, 1984). In either cases, there is a double voice: one is explicit and the other is implicit. The fact that they are intertwined, they generate a plurality of voices, which Ducrot calls "polyphonic authority". Clearly, in the utterances $a, b$ and $c$, the speaker $M$ tries to act on her co-speaker $T$. Unable to react to the pressure and eventual sanctions of her Mistress, Ticey settles for carrying out the latter's will. In other words, the co-speaker's rights are violated, for she suffers from her Mistress's authority. Symbolically, Ticey's misery is representative of the sufferings undergone by all black slaves.

To go ahead, let us underline that the ideology advocated by the colonists is deceptive. It disguises reality/truth and makes the lie emerge as a truthful norm. It also tames Blacks to an extreme level to the point that they are unaware that slavery is a groundless practice. Indeed, Gaines's novel provides various utterances in which white characters transgress the conversational maxims defined by Paule Grice (1989). To that critic, there are four conversational maxims, inter alia maxims of quantity (be informative), maxims of quality (be truthful), maxim of relation (be relevant), and maxims of manner (be clear). To learn more about the unilateralism of colonial ideology, it is relevant to show how it violates Grice's maxims. The following the utterances illustrate that view: " $f$ - We the noble, not them./g-God put us here to live the way we want live, that's in the Bible./ $h$ - And He put niggers here to see us live that way -that in the Bible too" (Gaines, 1971).

In the utterance $f$, the grammatical morpheme we and the objective personal pronoun them have some extratextual references. The morpheme, we refers to the Southern white community and them refers to the Northern white community. The morpheme we has an encompassing value; it includes the speaker $M$ who identifies himself with that community. The pronoun them also has an encompassing value. But, it exclusively takes into account the Yankees and the Northern authorities. Here, the speaker claims the superiority of the South to the North. By the use of the negation not, he affirms the nobility of the South on the one hand, and the poverty of the North on the other. In the utterance $g$, the same speaker $M$ uses some biblical words to justify the nobility of his community (South). In the utterance $h$, he still leans on the Bible; but here, he justifies the presence of black slaves in the South as God's will. In accordance with Grice's analysis, the speaker of the above utterances does not abide by his conversational maxims; he transgresses them through some biblical intertexts.

Implicitly, Gaines's novel reveals the deceptive, disguised, and falsifying characteristics of colonial ideology. The poetics of intertextuality exemplified by the use of biblical figures supports that view. Having no valid background, it leans on the Bible to impose its vision. This is accompanied by some repressive actions corroborated by the utterance $c$. Indeed, characterized by its non-conformist nature, colonial ideology rejects contradiction. It defends its ideals by all means, including unconventional ones. Better still, it denies competition and imposes its ideals as original values. This is why the interaction between slaveholders and slaves is always broken. Only the Masters or Mistresses have the right to speak and decide. 
That principle of domination is constraining and is not to be broken. Any contradictory acts are sanctioned. For instance, the following utterances show the unilateralism of colonial ideology: “ $i$ - You called me Ticey. My name ain't no more Ticey, it's Miss Jane Brown./j- My mistress face got red, her eyes got wide, and for about half a minute she stood there gaping at me./k- My mistress got tired beating me and told my master to beat me some" (Gaines, 1971).

This physical violence deeply contributes to traumatize the slaves and strengthen the authority of colonial ideology. In light of the preceding analysis, colonial ideology is violent, falsifying, authoritarian, denigrating, and deceptive. Examining Jane Brown, Croisille-Milhat indicates: "The slave girl [Jane Brown] claims her new name so well that she is whipped by her Mistress" (Croisille-Milhat, 2005). The analysis of the characteristics of colonial ideology demonstrates its unilateralism. However, it should be noted that the invasion of the South by the Yankee soldiers, changes the situation, for that compels the slaveholders are compelled to review their position. Better still, Emancipation brings a new order, which needs to be examined.

\section{The Discursive Matrix of Blacks' Emancipation}

At this step, the interest of this study is to scrutinize the characteristics of the Proclamation of Freedom and its ideological implications. It is worth noting that Gaines's text reveals that the South and the North are ideologically opposed. One supports the practice of slavery and the other considers it an inhumane practice, which is to be abolished.

Opposed to the union, which defends individual and collective liberties, the South continues to enslave Blacks. That practice enables the colonists to enhance their fortune. But, the presence of Yankee soldiers in the South shows a prevailing tension between the Southern and the Northern authorities - to impose the respect of Blacks' rights and consolidate a strong union, the North sends a punitive expedition of Yankees to the South. That mission compels the South to surrender. Indeed, the dialogical exchange between Corporal Brown (Yankee soldier) and Ticey (black slave) presages the end of slavery: “ $l$ - I'm just a' old ordinary Yankee soldier come down here to beat them Rebs and set you free. You want to be free, don't you, Ticey?/m- Yes, Master, I said./n- Well, just call me Mr. Brown, he said./o- And I'm go'n call you something else 'sides Ticey is a slave name, and I don't like slavery. I'm go'n call you Jane, he said./p- He said, I think you do like that name. Well, from now on your name is Jane. Not Ticey no more. Jane. Jane Brown. Miss Jane Brown. When you get older you can change it to what else you want. But till then your name is Jane Brown" (Gaines, 1971).

The utterances $l, m, n, o$, and $p$ illustrate an exemplary interaction between the Yankee soldier named Corporal Brown and the slave girl named Ticey. Those five utterances $l, m, n, o$, and $p$ show that the North is at war with the South. Semiotically, the Yankee soldier epitomizes freedom; he also reveals to Ticey that the North is free and that its authorities want the South to be so. In the utterance $p$, he reveals the young slave girl how denigrating her name is. To him, the name Ticey is exclusively linked to slavery. So, he urges the latter to give it up and take another one, which has no connection with slavery, such as Brown Jane. In essence, that naming process has nothing to do with the African one -It provides no information about the 
subjects' cultural roots; but it gives a sense of dignity and humanity to Ticey. As stated in the novel, Ticey is named after the Yankee soldier's daughter: " $q$ - That's right, I'll call Jane. That's my girl name back there in Ohio. You like for me to you that?” (Gaines, 1971). Clearly, the Yankee soldier's proposal makes Ticey aware and proud to such an extent that she begins to disobey her Mistress. In terms of semantic axis, those textual clues embody the raising action; they gradually contribute to the advent of the climax that is the Proclamation of Freedom: " $r$ - All right, I got news for y'all, the master said. Y'all free. Proclamation papers just come to me and they say y'all free as I am./s- If y'all stay I promise I'll be fair as I always been with y'all" (Gaines, 1971).

The utterance $r$ is an essential announcement, which is directly addressed to the whole slave community. This address is brief, but full of meanings. The speaker $M$ informs all the slaves that they are now free. In other words, the Southern authorities lose the war against the North; therefore, they are constrained to implement the decisions made by the Northern political figures. In the same utterance $(r)$, the grammatical morpheme they refers to the Northern political figures who are fiercely opposed to colonial ideology (slavery). To be specific, the decision made by the North is imposed on the Southern slaveholders' will. To Christopher Mulvey, "the hostility of Northern whites came as a shock to slaves arriving to find people who wanted no physical contact with them at all, did not want to be in the same room, car, space as them, were actually more distant than the Southern whites who lived surrounded by blacks" (Mulvey, 2006).

Distinctly, the South does not appreciate the interference of the North in their practice of slavery. Instead of using the morpheme we, the ex-Master uses the morpheme they. This means the South is not associated with the decision taken by the North. The ex-Master does not use the morpheme we, which has an inclusive scope. Through the use of the morpheme they his utterance discloses the disapproval of the South. Equally important, the emancipatory discourse enables the ex-slaves to assert themselves without being influenced by any decision or external pressure. Indeed, being free implies that one transforms one's situation as a dominated individual into another one, judged propitious, which provides oneself with more autonomy and helps to define oneself according to one's own norms without influencing one's former tormentor or even daring to copy his/her habits. The contrary definitely jeopardizes freedom and indirectly perpetuates dominion.

As stated above, the Proclamation of Freedom is a historical fact, which occupies a prominent function in The Autobiography -it brings deep changes between the ex-Masters and ex-slaves. In terms of "Transformation," the dialogue between the ex-Master and ex-slaves is established; the former speaks with courtesy and respect to the latter and vice versa. But in the background of this displayed and apparent politeness, there is a persistent and hidden attitude of selfishness and arrogance. This is what Paul Grice calls "conversational implicature". Indeed, there is an implicit value in the ex-Master's utterance. He is aware that the ex-slaves significantly sustain his economy, but he neither confesses it nor apologizes for being violent and unkind toward them at a certain moment. On the contrary, he proclaims his innocence and praises the quality of his former relationship with his victims. Worse still, he ignores all the humiliations he and his wife inflicted upon them. 
In the utterance $s$, he promises kindness and love to his victims, but such a promise is devoid of substance. This is paradoxical, hypocrite and remains a disavowal on his part, for he refuses to acknowledge his failures and mistakes. In reality, he is afraid of falling in a miserable social utterance. His family members are so worried that they cry; for instance, the following citation corroborates how worried the members of his family are: "t- Old Mistress and Young Mistress was standing in the door crying" (Gaines, 1971). Obviously, the colonists believe that their former victims will become their tormentors and them, the victims. They also believe that the victims (those who used to participate in the construction of their fortune) are the future nobles and them, the poor. This crying depicted in the utterance $t$ is full of hatred, contempt, and selfishness. Here, the ex-Masters expresses no love for the ex-slaves. What Gaines's novel depicts is the relevance of laws. Indeed, to Gaines the enforcement and respect of laws bring freedom. Obviously, the Proclamation of Freedom creates adequate conditions, which help the ex-slaves be free. But its contents are confusing: " $u$ - No, they just say y'all free, Isom," the master said. They don't care what y'all do, where y'all go. I'm the one who saying y'all can stay on if y'all want. If you stay, I got to work you on shares, and you work when you want. Can go to church and stay there and sing all day if you want. You free as I am, Isom" (Gaines, 1971).

Put another way, freedom should be entertained by daily deeds of the individuals whose lives are threatened, but also by those who proclaim it. Those follow-up actions can be either individual or collective. For instance, the questions raised by Unc Isom to convince his people are meaningful; through those questions, one realizes that Unc Isom knows more about slavery. Aged of 80 or 90 years of age, he is wise enough to give some pieces of advice to the others. Indeed, he interrogates the circumstances in which the Proclamation of Freedom occurs. To him, nothing guarantees that Proclamation. He frankly acknowledges that the ex-slaves' social status is pitiful; he also acknowledges the harms undergone by the ex-slaves, but he highly recommends the latter not to go elsewhere. He therefore suggests to the others to stay on the plantations of their ex-Master. He exhorts them to accept the latter's new proposals in order to protect themselves from murders and any other abuses. The oppositions noted on both sides (between Unc Isom and some of the members of his community) are essential because that dialectic aims to reach a final decision - the one, which can protect black community: " $v$ - Before y'all start out here heading anywhere, what y'all go'n eat? Unc Isom said Where y'all go'n sleep? Who go'n protect you from the patrollers?' (Gaines, 1971). Despite Unc Isom's proposal, some black females, such as Jane Brown and Big Laura decide to leave the plantation of their ex-Master. To Geneviève Fabre, " [Jane] listens with great attention to the argument that follows between the old man and the youth, each offering different interpretations of what 'free' may mean" (Fabre, 2006).

Plainly, it should be noted that the "Transformation" (Desmedt, 1989) described in The Autobiography is progressive -the advent of the Emancipation has been a long process. In a sense, it is one of the immediate results of the war between Yankees (North) and Secesh (South) -the victorious Army imposes its vision on the vanquished one. Better still, the Proclamation Freedom puts an end to several centuries of slavery; it helps Black females express their minds, narrate their experiences and sorrows. To Jerry Bryant, "in The 
Autobiography of Miss Jane Pittman, Ernest Gaines has not only created a new form for the expression of this truth but he has by means of that form increased its significance and given it a wider and deeper meaning" (Bryant quoted by Laurence Cossu-Beaumont, 2005). The Proclamation of Freedom paves new ways and arouses joy among Blacks -the following song is representative of the ex-slaves fascinating reaction: " $w$ - We free, we free, we free/We free, we free, we free/We free, we free, we free/Oh, Lordy, we free" (Gaines, 1971).

The morpheme free, which punctuates this four-verse song inaugurates, on the one hand, a new era in the relationship between North and South, and on the other hand, it puts an end to the ex-slaves' ill-treatments. Beyond those aspects, the morpheme free epitomizes post-emancipatory ideology. This is one of the textual clues, which contributes to the deconstruction of colonial ideology. To learn more about it, the following step will decipher its characteristics.

\section{The Post-Emancipatory Discursive Matrix}

This step deals with the "post-emancipatory discursive matrix;" it examines its characteristics. In The Autobiography, the period after the Proclamation of Freedom is turbulent. There is a tough opposition to colonial practices. The Republican Party decries all imperial practices. Gaines's text is one of the torchbearers, which gives voice to that period of uncertainty. His black female characters take an active part in the struggle against slavery -the latter vigorously combats irregular practices, which attempt to denigrate their emancipation. Be Brown Jane or Big Laura, in the background of their leadership, there is a firm commitment. They reject any idea of remaining under the colonists' governance. Both Brown Jane and Big Laura symbolize black commitment.

They do not have a partial view of freedom. To them, freedom should be or should be not. Those female characters do not admit conditioned or conditional freedom. The following utterance describes their revolutionary behaviors: " $x$ - The sun went down and we found the North Star. Big Laura put her bundle on her head, then she took that little girl in her arms and Ned by the hand and we started walking again. We walked and walked and walked and walked. Lord, we walked. I got so tired I wanted to drop. Some of the people started grumbling and hanging back, but they didn't know where else to turn and they soon caught up. Big Laura never stopped and never looked around to see who was following. That little girl clutched in her arms, Ned by the hand, she moved through them like she knowed exactly where she was going and wasn't go'n let nothing in the world get in her way" (Gaines, 1971). Understandably, Big Laura and Jane are charismatic beings. Indeed, their active behaviors show that they need full freedom. Analyzing black characters in The Autobiography, Ferdinand Kpohoue, Sènakpon A. Fortuné Azon, and Armand Kougnanvo underline: "Gaines's use of a female voice to chronicle over a hundred years of African American history, is proof of his belief in female leadership. Female leadership is one of the dominant characteristics of the narrative" (Kpohoue F. \& al, 2007). By their dynamic quest for freedom, they crush all forces that seem to be hostile to them, they challenge all obstacles.

Furthermore, it should be noted that the naming process adopted by the ex-slaves after the Emancipation is crucial in their lives. Indeed, that unprecedented renaissance of identity is 
more ideological than cultural; i.e., the ex-slaves are no longer the property of any colonists. Their names offer them opportunity to express their gratitude to some of the Northern political authorities. As proof, various ex-slaves decide to take names belonging to some famous political figures; they also take biblical names. To Kalpana Seshadri-Crooks, "marginalized people must be dealt with fairly, and all cultures must be given the right to survive in their authenticity" (Seshadri-Crooks, 1995). Let us underline that colonial naming process has no cultural background, this is part of the instruments used by colonizers to animalize Blacks. This is why the renaissance of identity threats the dominant colonial system; it deniggerizes Blacks' minds. This rupture discredits the ex-Masters' authority. Indeed, Blacks realize that their status as slaves is not natural, but depends on colonial ideology. So, to express their disapproval, they take various measures. For instance, they rename themselves and decide to leave their ex-Masters. The citation that follows describes the new era prevailing in Blacks' lives: "My new name Abe Washington, my new name Cam Lincoln, my new name Sherman S. Sherman; my new name Job/Lincoln, my new name Neremiah King, My new name Bill Moses" (Gaines, 1971).

In essence, those names are symbolical, for they identify black individuals and help them be socialized, but practically, they create a profound gap between Blacks and their ancestral roots. By textualizing that reality, Gaines discloses the danger to which Blacks are exposed. Critic Luc Boltanski provides a paramount study, which deals with the issues of onomastics in the dominated subject's life. Indeed, to him, the dominated subject does not have a cultural existence; i.e., he does not have a cultural identity. In the event of death, the latter's posterity remains without landmarks: "The dominated (whose limit is the slave) is, at least tendentially, a nameless. Even if, during his lifetime, and in restricted spaces, among his relatives, a sequence of phonemes serves to designate him, that sequence is not enough to compose a name. It can have only a practical existence (as a sobriquet). But, even if stabilized by the law, that simple appellation is destined to fade away with the physical disappearance of the one who was its bearer" (Translation mine) (Boltanski, 2009). As a matter of fact, the ex-slaves' new names cannot help their respective descendants to construct their cultural identity.

It is certain that the naming process, which follows the Proclamation of Emancipation symbolizes Blacks' desire to redefine themselves, but it has no cultural value -those names acquired, are part of the measures dictated by the circumstances. The truly redefinition is the one advocated by Stokely Carmichael and Charles V. Hamilton: "Black people must redefine themselves, and only they can do that. Throughout this country, vast segments of the black communities are beginning to recognize the need to assert their own definitions, to reclaim their history, their culture, to create their sense of community and togetherness. There is a growing resentment of the word 'Negro,' for example, because this term is the invention of our oppressor; it is his image of us that he describes. Many Blacks are now calling themselves African-Americans, Afro-Americans, black people because that is our image of ourselves. When we begin to define our own image, the stereotype -that is, lies -that our oppressor has developed will begin in the white community and end there" (Carmichael \& Hamilton, 1967). Gaines's novel implicitly urges black folks to revisit their cultural roots (Africa), to learn more about their history and discover themselves. 
From an enunciative perspective, the post-emancipatory era is characterized by self-affirmation. The grammatical morpheme $I$ and the stative verb be are recurrent in the subjects' discourse. The following utterance illustrates that view: "I, I, I can be Brown" (Gaines, 1971). There is a real awakening of consciousness, which enables black females to emancipate from the ex-Mistresses. By asserting themselves black females emerge -they begin to revitalize their own experience. This plurivocality noticed here, is representative of the colonists' lack of control. Indeed, Emancipation renders Blacks unsubmissive; they all speak out and decide to externalize their disarray and sorrow. Indeed, in The Autobiography, both male and female characters become depository of history. Jane, one of Gaines's involved characters narrates her experience as follows: "Some people don't beat their niggers, they sure used to beat us, I told her. Old Mistress beat us with the first thing her hands fell on. And had the nerve to cry when they said freedom had come. I ain't studying about her" (Gaines, 1971).

Obviously, the emancipation claimed by Jane Brown is the one, which is not subject to any external force. To Michel Foucault, "the freeing of difference requires thought without contradiction, without dialects, without negation; thought accepts divergence; affirmative thought whose instrument is disjunction, thought of the multiple -of the nomadic and dispersed multiplicity that is not limited or confined by the constraints of the le same; thought that does not conform to a pedagogical model" (Foucault quoted by David Huddart, 2008).

Through Jane's voice, Gaines advocates justice, which admits the existence of the others without contradiction. But as the story unfolds, the author decries the problematic nature of the emancipation granted to Blacks. To Valerie Melissa Babb, "[The Autobiography is a] neo-narrative. In her analysis, she defines Gaines's work as follows: "Neo-Slave narratives provide a means of seeing a frequently represented institution differently. They go beyond the binaries of slaves and masters, victims and victimizers, to show the pervasiveness and complexity of a social system" (Babb, 2017). Explicitly, American institutions are differently portrayed by Gaines. Indeed, politicians are ideologically divided. Freedom is proclaimed, but slavery still keep on worsening Blacks' lives. Various textual clues corroborate the ambivalence of the post-emancipatory era. Blacks are officially declared as free people, but they are prevented from taking profit from their emancipation; for example, the massacre of the ex-slaves by the members of Ku Klux Klans attests that there is no real freedom. That guerrilla is anti-abolitionist and is responsible for enforcing the colonists' decision; it combats the ideals of Blacks' emancipation.

Symbolically, Jane fails to find Corporal Brown. This illustrates Blacks' impossibility to be totally free -no legal and regular Forces is committed to ensuring strict adherence to the ideals of the Proclamation of Freedom. Also, the division (reluctance) and misunderstandings within black community makes the issue of emancipation impossible. In the same community, there are black Democrats and black Republicans. The narrator indicates: " $z$ - It was the Republicans that had freed us, and it was the Republicans that freed us, and it was the Republicans that had the Freedom Beero there to look after us. They wanted us to take interest in what was going on. They wanted us to vote -and vote Republican. The Democrat Party was for slavery, they said, and believe it or not, there was niggers in the Democrat at 
work" (Gaines, 1971). In the utterance (z), Gaines displays the real causes of Blacks' sufferings. The first cause is that they are disunited. That disunity ruins all their endeavors to entirely get rid of imperialism. When some work hard to banish any forms of humiliations, others ally with Whites to keep Blacks in the status quo. As described by Gaines here, disunity transcends American borders, for it is narrowly linked to the one experienced by Blacks in the ex-colonies formerly ruled by the Great. Indeed, Emancipation remains insignificant, for black individuals are dependent on the colonizer. As a result, independence remains discredited. In terms of literary, historical and political scopes, Gaines innovates the traditional autobiography. He does not narrate his life, but rather that of the community to which he belongs. He practices ethno-biography; his text retraces all the painful experiences undergone by black community and the voice used to do so is the female one.

Thus, black history (on Southern plantations) is vividly rendered. This serves as a lesson and tool to warn any eventual troubles. Actually, Gaines's novel urges politicians to give up barbaric practices, i.e., to change their attitudes as the Epistle to the Colossians advocates: "Put off the old man's ways that you were, and put on the new man, who advances toward true knowledge by renewing himself in the image of his creator" (Translation mine) (Epistle to the Colossians quoted by Julia Kristeva, 1988). This is the way out to create true freedom and a world of justice. Homi Bhabha goes along with that view: "It is through the effort to recapture the self and to scrutinize the self, it is through the lasting tension of their freedom that men will be able to create the ideal conditions of existence for a human world" (Bhabha, 1994). Explicitly, Gaines's novel encourages both colonized and colonizers to appropriate universal brotherhood -the one which destroys cultural barriers and advocates mutual love among humans.

\section{Conclusion}

To conclude this work, it is worth indicating its objective, its articulations, the methodological tool used to carry it out, and its results. With reference to this requirement, the current work aimed to bring out the literary significance of three ideologies, which are respectively rooted in colonial, emancipatory, and post-emancipatory discourses. Together, they constitute a "discursive heterogeneity" in Gaines's text. This study showed that colonial ideology is intransigent, unilateral, and hostile to all kinds of contradiction. As far as the emancipatory ideology is concerned, it contributes to change the relationships between the ex-masters and ex-slaves. Both Blacks and Whites talk to each other; this bring hope and freedom to Blacks. As to the post-emancipatory ideology, it provides Blacks with ambivalent freedom, for daily chores are strictly forbidden, but Blacks' rights continue to be violated. Worse still, inequalities between Whites and Blacks persist. The analytical approach, which made those explanations possible is narrative semiotics. With its properties, the semantic axis of The Autobiography has been defined. On that axis, colonial, emancipatory, and post-emancipatory discourses have been respectively analyzed. It should therefore be noted that the methodological tool gave the characteristics of the three steps: $\left(\mathrm{S}_{(\mathrm{E})} ; \mathrm{T}_{(\mathrm{RA} / \mathrm{C} / \mathrm{FA})}\right.$; $\mathrm{S}_{(\mathrm{E})}$. At the first step $S$, Blacks are slaves; at the second step $T$, they are emancipated, and at the third step $S^{\prime}$, they are apparently free, but they ideologically remain under Whites' guidance. If the results obtained seem satisfactory, it must be recognized that Gaines's novel is more 
symbolical than ever, its aesthetic scope fundamentally takes into account the economic and cultural issues, which worsen Blacks' lives in the $20^{\text {th }}$ century.

\section{References}

Adeboye A., J. (2008). The Shifting Features of Leadership in Ernest Gaines's The Autobiography of Miss Pittman. Revue du C.A.M.E.S., Serie B, 10(1).

Babb V. M. (2017). A History of the African American Novel. Cambridge, Cambridge University Press. https://doi.org/10.1017/9781107448773.010

Bhabha, H. K. (1994). The Location of Culture. New York, Routledge.

Boltanski, L. (2009). De la critique. Précis de sociologie de l'émancipation. Paris, Éditions Gallimard.

Carmichael, S., \& Hamilton, C. V. (1976). Black Power: The Politics of Liberation in America. New York, Random House.

Cossu-Beaumont, L. (2005). La Réception de The Autobiography of Miss Jane Pittman: Du consensus à la polémique. Tours, Presses universitaires François-Rabelais. Retrieved March 22, 2021 from http://www.openedition.org/6540

Croisille-Milhat, V. (2005). The Autobiography of Miss Jane Pittman: La Mémoire de Miss Jane ou une h/Histoire à visage humain. Tours, Presses universitaires François-Rabelais. https://doi.org/10.4000/books.pufr.5428

Ducrot, O. (1984). Le Dire et le dit. Paris, Éditions de Minuit.

Ettien, Y. (2014). Ernest J. Gaines's Miss Jane Pittman: A Symbol of the Black Female Abolitionist Struggle. Philological Studies and Research - Applied Foreign Language Series, 13, 201-209.

Evayoulou, B. (2011). The Autobiography of Miss Jane Pittman and the Tradition of the African American Historical Novel. Annales de l'Université Marien NGOUABI, 12(1). Retrieved March 22, 2021 from https://www.annalesumng.org/index.php/lsh/article/view112

Everaert-Desmedt, N. (1989). Sémiotique du récit. Bruxelles, De Boeck.

Fabre, G. (2006). Conversations with Miss Jane. Transatlantica. https://doi.org/10.4000/transatlantica.931

Fontanille, J. (2003). Sémiotique du discours. Limoges, PULIM.

Gaines, E. J. (1971). The Autobiography of Miss Jane Pittman. New York, Dial Press.

Grice, H. P. (1975). Logic and Conversation. Syntax and Semantics, 3. Speech Acts, New York, Academic Press.

Huddart, D. (2007). Postcolonial Theory and Autobiography. Oxford, Routledge. https://doi.org/10.4324/9780203306574 
Kerbrat-Orecchioni, C. (1986). L'Implicite. Paris, A. Colin.

Kpohoue, F. \& al. (2007). African Americans' Empowerment through Individual Endeavor and Local Leadership in The Autobiography of Miss Jane Pittman by Ernest Gaines. Revue des Sciences du Langage et de la Communication-RESCILAC-UAC, $\mathrm{N}^{\circ} 5-2^{\text {nd }}$ semestre, décembre.

Kristeva, J. (1988). Étrangers à nous-mêmes. Paris, Fayard.

Mbembe, A. (2013). Critique de la raison nègre. Paris, La Découverte «Cahiers libres».

Mostafaee, J. (2016). Investigating Identity, Ambivalence, Hybridity: A Bhabhaian Reading of J. M. Coetzee's Foe and Disgrace. Advances in Language and Literary Studies, 7(6). https://doi.org/10.7575/aiac.alls.v.7n.6p.163

Mulvey, C. (2006). The History of Miss Jane Pittman. Transatlantica. https://doi.org/10.4000/transatlantica.951

Raynaud, C. (2005). The Autobiography of Miss Jane Pittman: Generic Twists and Trappings. É, 58-4, pp. 440-455. https://doi.org/10.3917/etan.584.0440

Reuter, Y. (2011). Introduction à l'analyse du roman. Paris, Armand Colin.

Savin, A. (2005). The Autobiography of Miss Jane Pittman: Some Generic Distinctions. Cahiers de recherches afro-américaines: Transversalités (pp. 11-24). Tours, Presses universitaires François-Rabelais. https://doi.org/10.4000/books.pufr.5426

Seshadri-Crooks, K. (1995). At the Margins of Postcolonial Studies. ARIEL: A Review of International English Literature, 26(3).

Siouffi, G., \& Raemdonck, D. V. (1999). 100 fiches pour comprendre la linguistique. Paris, Les Éditions Bréal.

Thomières, D. (2011). Man's Way and Woman's Way in The Autobiography of Miss Jane Pittman. The Mississippi Quarterly, 64(1/2), pp. 219-234. https://doi.org/10.1353/mss.2011.0032

\section{Notes}

Note 1. For any other references to The Autobiography of Miss Jane Pittman, we will use The Autobiography.

Note 2. $\mathrm{S}(\mathrm{E})=$ Colonial; $\mathrm{T}(\mathrm{RA} / \mathrm{C} / \mathrm{FA})=$ Emancipatory; $\mathrm{S}^{\prime}(\mathrm{E})=$ Post-Emancipatory.

Note 3 . Ticey $=T$; Mistress $=M$; Master $=M$. 


\section{Copyrights}

Copyright for this article is retained by the author(s), with first publication rights granted to the journal.

This is an open-access article distributed under the terms and conditions of the Creative Commons Attribution license (http://creativecommons.org/licenses/by/4.0/) 